\title{
Development of a Discriminative and Biorelevant Dissolution Test Method for Atorvastatin/ Fenofibrate Combination with Appliance of Derivative Spectrophotometry
}

\author{
Türev Spektrofotometrik Yöntem ile Atorvastatin/Fenofibrat \\ Kombinasyonunda Ayırıcı ve Biyouyumlu Çözünme Testi Metodunun \\ Geliştirilmesi
}

\author{
(D) Panukumar Durga ANUMOLU*, (D) Sunitha GURRALA, (D) Subrahmanyam Chavali VENKATA SATYA, (D) Santoshi Vani POLISETTY, \\ (D) Anjana RAVINDRAN, (D) Radhagayathri ACHANTA \\ Osmania University, Gokaraju Rangaraju College of Pharmacy, Department of Pharmaceutical Analysis, Hyderabad, India
}

\begin{abstract}
Objectives: Nowadays, the market is flooded with combinations of drugs in various dosage forms, but there is a lack of official methods to quantify them. A single dissolution test method for the analysis of combined dosage form is preferred for simplification of quality control testing.

Materials and Methods: If the developed dissolution medium mimics the biorelevant and discriminating dissolution procedure for drug products with limited drug aqueous solubility it is a useful tool for qualitative forecasting of the in vivo behavior of formulations.

Results: Dissolution profiles were evaluated for atorvastatin and fenofibrate in capsules, using a paddle-type United States Pharmacopeia dissolution apparatus in $900 \mathrm{~mL}$ of medium at $50 \mathrm{rpm}$ and $37 \pm 0.5^{\circ} \mathrm{C}$. The best medium was $900 \mathrm{~mL}$ of $0.5 \% \mathrm{w} / \mathrm{v}$ sodium lauryl sulfate. The cumulative \% dissolution was more than $85 \%$ within 45 min for marketed tablets. The proposed dissolution test conditions have discriminative power, dissimilarity factor $\left(f_{1}\right)$ values are low $(12-16 \%)$, and similarity $\left(f_{2}\right)$ factor values are also low $(45-48 \%)$. Hence the use of $0.5 \% \mathrm{w} / \mathrm{v}$ sodium lauryl sulfate solution is justified.

Conclusion: The dissolution method was validated (\% relative standard deviation $<2$ ). To quantify both drugs simultaneously, a second derivative spectrophotometric method was established ( $\lambda_{\max } 281 \mathrm{~nm}$ and $296 \mathrm{~nm}$, respectively, for atorvastatin and fenofibrate) in acetate buffer, pH 2.8 solution.

Key words: Derivative spectrophotometry/quantification simultaneously, atorvastatin/fenofibrate combined dosage form, biorelevant/discriminative dissolution method
\end{abstract}

\section{öz}

Amaç: Günümüzde, çeşitli dozaj formlarında etkin madde kombinasyonlarına rağbet edilmektedir, ancak bunlardaki etkin maddeleri tayin etmek için farmakope yöntemleri bulunmamaktadır. Bu çalışmada, kombine dozaj formunun analizi için kalite kontrol testini sadeleştirmek amacıyla tek bir çözünme testi yöntemi tercih edilmiştir.

Gereç ve Yöntemler: Suda çözünürlüğü sınırlı olan ilacın çözünme yöntemi için geliştirilen çözünme ortamı in vivo davranışlarının kalitatif tahmininde biyouyumlu bir yöntem olarak kullanışlı bulunmuştur.

Bulgular: Atorvastatin ve fenofibrat içeren kapsüllerde çözünme profilleri, $37 \pm 0.5^{\circ} \mathrm{C}^{\prime} \mathrm{de}, 50 \mathrm{rpm}$ ve $900 \mathrm{~mL}$ ortam içinde bir palet tipi Amerikan Farmakopesi çözünme cihazı ile değerlendirildi. En iyi ortam, $900 \mathrm{~mL} \% 0.5$ a/h sodyum lauril sülfattır. Piyasadaki tabletler için kümülatif \% çözünme, 45 dakika içinde \%85'ten fazla olmuştur. Önerilen çözünme testi koşulları ayırt edici bir güce sahiptir, farklıık faktörü $\left(f_{1}\right)$ değerleri düșüktür (\%12-

16) ve benzerlik $\left(f_{2}\right.$ ) faktör değerleri de düşüktür (\%45-48). Bu nedenle, \%0.5 w/v sodyum lauril sülfat çözeltisinin kullanımı uygundur.

*Correspondence: E-mail: panindrapharma@yahoo.co.in, Phone: +09010014734 ORCID-ID: orcid.org/0000-0001-5010-7488

Received: 14.11.2017, Accepted: 20.12.2017

๑Turk J Pharm Sci, Published by Galenos Publishing House. 
Sonuç: Çözünme yöntemi valide edilmiştir (\% relatif standart sapma <2). Her iki etkin maddeyi pH 2.8 asetat tamponu çözeltisi içinde aynı anda tayin etmek için, ikinci türev spektrofotometrik yöntemde atorvastatin ve fenofibrat için sırasıyla $\lambda_{\max } 281 \mathrm{~nm}$ ve $296 \mathrm{~nm}$ kullanılmıştır.

Anahtar kelimeler: Atorvastatin/fenofibrat kombine dozaj formu, biyouyumlu/ayırıcı çözünme yöntemi

\section{INTRODUCTION}

Dissolution is considered one of the most routinely performed quality control tests on dosage forms to ensure uniformity and reproducibility of production batches. Process parameters and ingredients are optimized during product development, ${ }^{1-3}$ and whether changes made to the formulations or their manufacturing processes are likely to affect the performance in the clinic or not are decided on using dissolution methods. ${ }^{4}$ An immediate release dosage form is designed to deliver the drug rapidly into systemic circulation. Hence, dissolution may become the rate limiting step for its absorption. The absorption of a drug substance may vary with diverse parameters like its solubility and permeability in the conditions associated with the gastro-intestinal (GI) tract after oral administration. ${ }^{5-7}$ Taking all these points into consideration, there is a need to put more research efforts into developing in vitro Gl fluids that mimic in vivo conditions. Discriminative dissolution has the ability to differentiate the dissolution profiles between manufacturing process variations and product composition variations. ${ }^{8-10}$

Fenofibrate, chemically known as isopropyl 2-[4-(4-chlorobenzoyl)2-phenoxy] methyl propanoate, is a fibric acid derivative with lipid regulating properties exerting its therapeutic effects through activation of peroxisome proliferator activated receptor $\alpha$ (Figure 1A). Atorvastatin calcium, chemically $\left[R-\left(R^{*}, R^{*}\right)\right]-2-(4-F l u o r o p h e n y l)-\beta, \delta$-dihydroxy-5-(1methylethyl)-3-phenyl [(phenylamino)carbonyl]-1H-pyrrole1-heptanoic acid, is an HMG-Co A reductase inhibitor with hypolipidemic properties (Figure 1B).11,12 The combined dosage form of fenofibrate and atorvastatin is therapeutically used for hyperlipidemic patients. Fixed dose combination of drugs has been a challenge; if possible a single dissolution method is preferred to simplify quality control testing procedures. ${ }^{13-15} \mathrm{Few}$ analytical methods were reported for simultaneous quantification of atorvastatin calcium and fenofibrate by high-performance liquid chromatographic and spectrophotometric methods. ${ }^{16-19}$ Derivative spectroscopy may be used with minimum error for the quantification of one analyte. ${ }^{20,21}$ Overlaid zero-order spectra exhibit a similar nature and overlapping for atorvastatin calcium with fenofibrate denotes development of the derivative graphical method. To the best of our knowledge, only one first and second derivative spectrophotometric method have been reported for simultaneous quantification of atorvastatin (ATV)
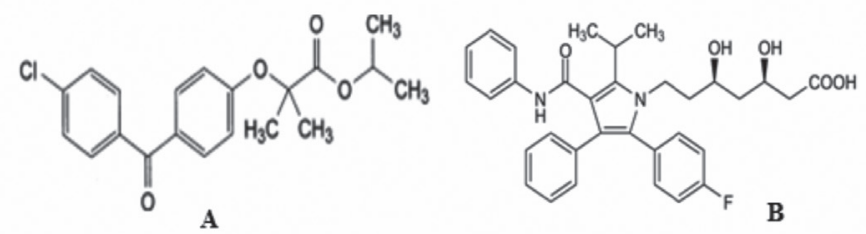

Figure 1. Chemical structure of fenofibrate $(A)$ and atorvastatin (B) and fenofibrate (FEN) in methanol as solvent, but methanol is environmentally toxic and more expensive than aqueous buffers and one wavelength is $245 \mathrm{~nm}$, which is normally originated from the benzenoid ring system. Since several compounds may contain benzene rings, it is always better to avoid $245 \mathrm{~nm}$ and select a wavelength away from it. Literature data signify the need for a simple, economical, ecofriendly, and specific analytical method for simultaneous quantification of ATV and FEN combination in tablets and dissolution samples. The development of a single dissolution method is practically challenging due to their low water solubility for combination of atorvastatin and fenofibrate. Keeping these points in mind, an attempt is made to develop and validate a single dissolution test for simultaneous quantification with application of a simple derivative spectrophotometric technique.

\section{MATERIALS AND METHODS}

\section{Materials}

Atorvastatin and fenofibrate were obtained as gift samples from Dr. Reddy's Laboratories Limited (Hyderabad, India). Methanol, hydrochloric acid, ortho-phosphoric acid, potassium di hydrogen orthophosphate, sodium hydroxide, sodium chloride, and sodium acetate were purchased from Sd FineChem Limited (Mumbai, India); sodium lauryl sulfate (SLS), tween 80, cetrimide, lecithin, and sodium taurocholate were purchased from Himedia Ltd (Mumbai, India). Double distilled water was used throughout the study. Atorvastatin and fenofibrate combination tablet formulations-Atocor (Dr. Reddy's Laboratories) and Fibator (Sun Pharma, Sikkim, India)-were obtained from the local market.

\section{Instrumentation}

A double beam 1800 UV-visible spectrophotometer (Shimadzu, Japan), dissolution apparatus (Electrolab TDT-08L), analytical balance (Shimadzu AUX 220, Japan), tablet compression machine (Lab Press-CIP Machineries, Ahmedabad, India), hardness tester (Secor, Hyderabad, India), pH meter (Elico, Hyderabad, India), and ultrasonic cleaner were used for the study (calibration of instruments were done according to standard procedures).

\section{Analytical method}

The first-order derivative overlaid spectra of atorvastatin calcium and fenofibrate denoted that there was no zero crossing point for atorvastatin calcium for quantification of fenofibrate (Figure 2). Hence, the first-order derivative spectrum was not suitable for simultaneous estimation and this problem was minimized by the second-order derivative method, which permitted selection of the suitable wavelengths to make the quantification possible with zero crossing, where fenofibrate had zero absorbance at $281 \mathrm{~nm}$, while atorvastatin calcium gave a significant derivative response; likewise atorvastatin gave zero absorbance at 296 


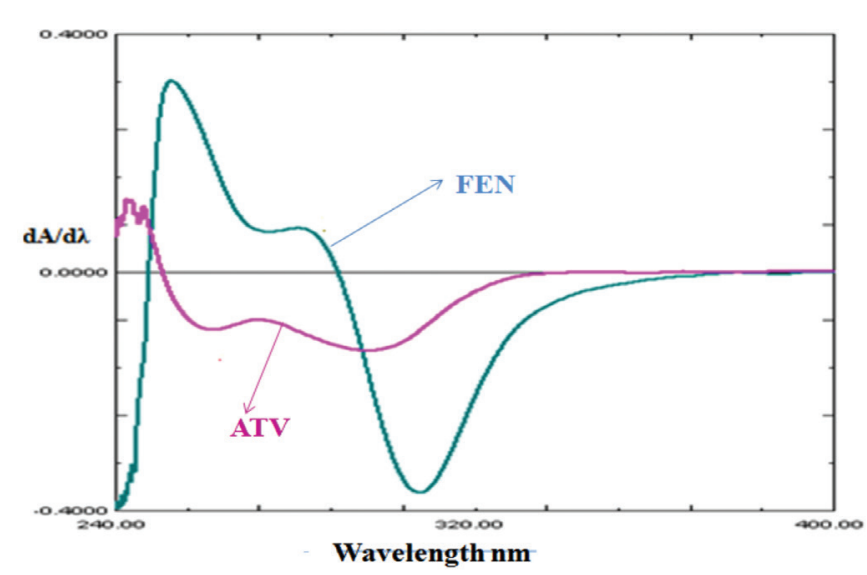

Figure 2. First-order UV overlay spectra of atorvastatin $(10 \mu \mathrm{g} / \mathrm{mL})$ and fenofibrate $(10 \mu \mathrm{g} / \mathrm{mL})$ in acetate buffer, $\mathrm{pH} 2.8$

UV: Ultraviolet, ATV: Atorvastatin, FEN: Fenofibrate

$\mathrm{nm}$, while fenofibrate gave a significant derivative response. Therefore, $281 \mathrm{~nm}$ and $296 \mathrm{~nm}$ were selected for estimation of atorvastatin calcium and fenofibrate, respectively.

\section{Dissolution test conditions}

The log $p$ values of atorvastatin calcium and fenofibrate were 6.36 and 5.28, respectively, indicating low water solubility and so the development of a single dissolution method for this combination is a challenge and single in vitro dissolution studies were not reported for this combination along these lines. An attempt was made to develop and validate a single dissolution test for atorvastatin calcium and fenofibrate in combined tablets.

Atorvastatin (10 mg) and fenofibrate (145 mg) bulk drug filled capsules were evaluated for dissolution profile in $900 \mathrm{~mL}$ of seven buffers of distinct $\mathrm{pH}(1.2 / 2.8 / 3.6 / 4.7 / 5.6 / 6.8$ and 7.4), biorelevant media such as SGF ( $\mathrm{pH} 1.2)$, SIF $(\mathrm{pH} 7.5)$, FaSSIF $(\mathrm{pH} 6.5)$, FeSSIF ( $\mathrm{pH} 5.0)$, modified fasted state $(\mathrm{pH} 6.5)$ and fed state ( $\mathrm{pH}$ 5.0) simulated intestinal fluids) and three different surfactants and at 2 different concentrations at 50 rpm using type 2 - United States Pharmacopeia dissolution apparatus and samples were withdrawn for $60 \mathrm{~min}$, being replaced with the same volume of fresh medium. Samples withdrawn were evaluated with the regression equation of the proposed analytical technique for quantification of dissolved drug, followed by a plot against time. A combination of these media was utilized for identifying the optimized dissolution medium, in which the highest drug release, stability, and sink conditions were obtained, and it was chosen as the in vitro dissolution medium.

\section{Discriminatory power of the dissolution method}

The dissolution method's ability to discriminate was ascertained using tablets punched under distinct conditions, such as a discrete manufacturing process (hardness of $5.0 \mathrm{~kg} /$ $\mathrm{cm}^{2}$ and $8.0 \mathrm{~kg} / \mathrm{cm}^{2}$ ) and discrete product composition (with/ without disintegrant). The dissolution-profiles in test conditions were examined and their data were estimated with factors of comparison $\left(f_{1}\right.$ and $f_{2}$ ).

\section{Stability determination}

Sample solutions withdrawn for the optimized dissolution medium were analyzed at time 0 ; consequently samples were kept for $24 \mathrm{~h}$ and $48 \mathrm{~h}$ and analyzed by the proposed method.

\section{Validation of the dissolution method}

Validation of the dissolution method is required to ensure that a proposed dissolution method is scientifically and experimentally sound, obtaining results for specificity, linearity, accuracy, and precision as per standard guidelines.

The method's specificity was assessed by comparing the spectra obtained from the commercial formulations and the synthetic mixture from standard solutions by preparing similar dose ratios of synthetic and tablet dosage forms. Then the analytical method was applied in order to check if any component of the formulation could generate a response or an absorption wavelength similar to that of the drugs.

Linearity was determined with standard concentrations of atorvastatin (2-12 $\mu \mathrm{g} / \mathrm{mL})$ and fenofibrate $(1-35 \mu \mathrm{g} / \mathrm{mL}$ ) quantified with the second derivative spectrophotometric technique. Then absorbance was recorded and a calibration curve was constructed by plotting the analyte response versus the drug concentrations.

Intra-day and inter-day precision studies were evaluated as per International Conference on Harmonization guidelines, in which six tablets were subjected to the dissolution test conditions, on the same day (intra-day precision) and for three consecutive days (inter-day precision); then \% RSD was calculated.

Accuracy studies were conducted using standard addition method where known amounts of drugs at $80 \%, 100 \%$ and $120 \%$ of the formal assay of atorvastatin and fenofibrate were added to the placebo sample in the dissolution medium, which was further subjected to the proposed method; then percentage recovery and relative standard deviation (\% RSD) were computed for each concentration.

\section{RESULTS AND DISCUSSION}

\section{Development of the dissolution method}

The selection of the dissolution test method was based on the dissolution profiles of atorvastatin $(10 \mathrm{mg}$ ) and fenofibrate (145 $\mathrm{mg}$ ) bulk drug filled capsules using a USP type 2 apparatus at a paddle speed of $50 \mathrm{rpm}$ and selection of a dissolution medium for adequate solubility and stability of both atorvastatin calcium and fenofibrate was necessary for this dissolution method. The log $p$ values of atorvastatin calcium and fenofibrate respectively were 6.36 and 5.28, denoting low water solubility. Several compendia dissolution media were screened; these include various buffer media ( $\mathrm{pH} 1.2$ to 7.4 ), surfactant media, and several biorelevant media. However, the results showed that the dissolution rate of atorvastatin was maximum in weak acidic buffers because of the specific interaction but the dissolution rate of fenofibrate was less than $2 \%$ in all buffers, indicating that fenofibrate dissolution was independent of $\mathrm{pH}$ due to the absence of ionizable groups (Table 1). Both drugs showed higher dissolution in $0.5 \% \mathrm{w} / \mathrm{v}$ SLS medium than in other dissolution media. Dissolution medium with low concentration 
of SLS may resemble the gastric environment of our body, and hence this medium is useful for correlating in vitro dissolution behavior of atorvastatin and fenofibrate in combined dosage form with their in vivo performance. This medium can also be a useful quality control tool and the selected dissolution test conditions are USP apparatus 2 at paddle speed $50 \mathrm{rpm}$ in a medium of $0.5 \% \mathrm{w} / \mathrm{v}$ SLS. Therefore, dissolution studies were performed for commercial tablets (Atocor and Fibator) in optimized dissolution test conditions.

\section{In vitro dissolution profiles of commercial tablets}

Dissolution studies on Atocor and Fibator tablets were performed with the optimized dissolution test medium of $0.5 \%$ w/v SLS, using a USP type 2 apparatus at paddle speed of $50 \mathrm{rpm}$ at temperature $37 \pm 0.5^{\circ} \mathrm{C}$ and these results are shown in Figure 3 and 4 . They indicated that about $85 \%$ of both atorvastatin and fenofibrate was released in $45 \mathrm{~min}$ from the two brands. In fact, fenofibrate exhibited only $50 \%$ dissolution in 60 min (Table 1). On the other hand, tablets exhibited 85\%

\begin{tabular}{|c|c|c|}
\hline \multirow[t]{2}{*}{ Dissolution media } & \multicolumn{2}{|c|}{$\begin{array}{l}\% \text { Drug release } \\
\text { mean } \pm \text { standard deviation } \\
(n=12)\end{array}$} \\
\hline & ATV & FEN \\
\hline $0.1 \mathrm{~N}$ hydrochloric acid & $18.40 \pm 0.09$ & $1.16 \pm 0.07$ \\
\hline Acetate buffer, $\mathrm{pH} 2.8$ & $29.56 \pm 0.04$ & $1.47 \pm 0.07$ \\
\hline Acetate buffer, pH 3.6 & $41.40 \pm 1.66$ & $1.14 \pm 0.08$ \\
\hline Acetate buffer $\mathrm{pH} 4.7$ & $48.43 \pm 2.16$ & $1.12 \pm 0.10$ \\
\hline Phosphate buffer, pH 5.6 & $92.45 \pm 2.96$ & $0.93 \pm 0.04$ \\
\hline Phosphate buffer, pH 6.8 & $95.45 \pm 4.18$ & $1.02 \pm 0.02$ \\
\hline Phosphate buffer, $\mathrm{pH} 7.4$ & $86.59 \pm 1.40$ & $1.04 \pm 0.05$ \\
\hline $\begin{array}{l}\text { SGF (simulated gastric fluid without } \\
\text { enzyme) }\end{array}$ & $50.28 \pm 3.71$ & $1.04 \pm 0.06$ \\
\hline SIF (simulated intestinal fluid) & $87.59 \pm 2.40$ & $1.94 \pm 0.05$ \\
\hline $\begin{array}{l}\text { BFaSSIF (blank fasted state } \\
\text { simulated intestinal fluid) }\end{array}$ & $95.88 \pm 1.76$ & $1.20 \pm 0.06$ \\
\hline $\begin{array}{l}\text { BFeSSIF (blank fed state simulated } \\
\text { intestinal fluid) }\end{array}$ & $92.46 \pm 2.45$ & $1.33 \pm 0.08$ \\
\hline $\begin{array}{l}\text { MFaSSIF (modified fasted state } \\
\text { simulated intestinal fluid) }\end{array}$ & $98.00 \pm 1.19$ & $5.33 \pm 0.75$ \\
\hline $\begin{array}{l}\text { MFeSSIF (modified fed state } \\
\text { simulated intestinal fluid) }\end{array}$ & $92.45 \pm 0.60$ & $4.15 \pm 0.21$ \\
\hline Cetrimide, $0.25 \% \mathrm{w} / \mathrm{v}$ & $98.33 \pm 5.41$ & $7.08 \pm 0.07$ \\
\hline SLS $0.25 \% \mathrm{w} / \mathrm{v}$ & $94.00 \pm 5.27$ & $30.54 \pm 0.54$ \\
\hline Tween $800.25 \% \mathrm{v} / \mathrm{v}$ & $40.87 \pm 0.02$ & $2.36 \pm 0.17$ \\
\hline SLS $0.5 \% \mathrm{w} / \mathrm{v}$ & $95.42 \pm 2.56$ & $50.54 \pm 0.53$ \\
\hline
\end{tabular}

ATV: Atorvastatin, FEN: Fenofibrate, USP: United States Pharmacopeia, SLS: Sodium lauryl sulfate dissolution in $45 \mathrm{~min}$; this means that the inactive ingredients in the tablets also supported the dissolution. Such a factor should also be kept in mind while optimizing the dissolution conditions. Atorvastatin components of the tablet formulation exhibited $88 \%$ dissolution in $45 \mathrm{~min}$, whereas the pure drug exhibited $92 \%$ dissolution in $45 \mathrm{~min}$ in the same medium. Thus the proposed dissolution medium satisfactorily reproduced the dissolution characteristics of atorvastatin and fenofibrate with initial lag time of 5 min for drug dissolution but lag time was more pronounced in the case of fenofibrate. This trend was familiar from the chemical structure of fenofibrate (no functional groups responsible for ionization). Furthermore, both drugs are hydrophobic as indicated by the log $p$ values, 6.36 and 5.28, respectively, for atorvastatin and fenofibrate. From 5 min to $60 \mathrm{~min}$, the dissolution behavior was gradual and linear, which again reflected the hydrophobic nature of the drugs.

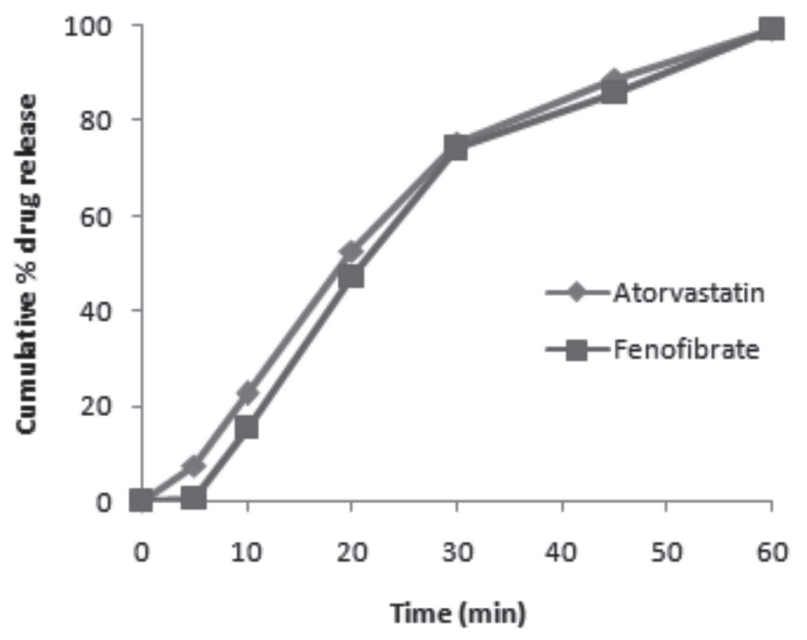

Figure 3. In vitro dissolution profiles of Atocor tablets in 0.5\% W/V SLS medium

SLS: Sodium lauryl sulfate

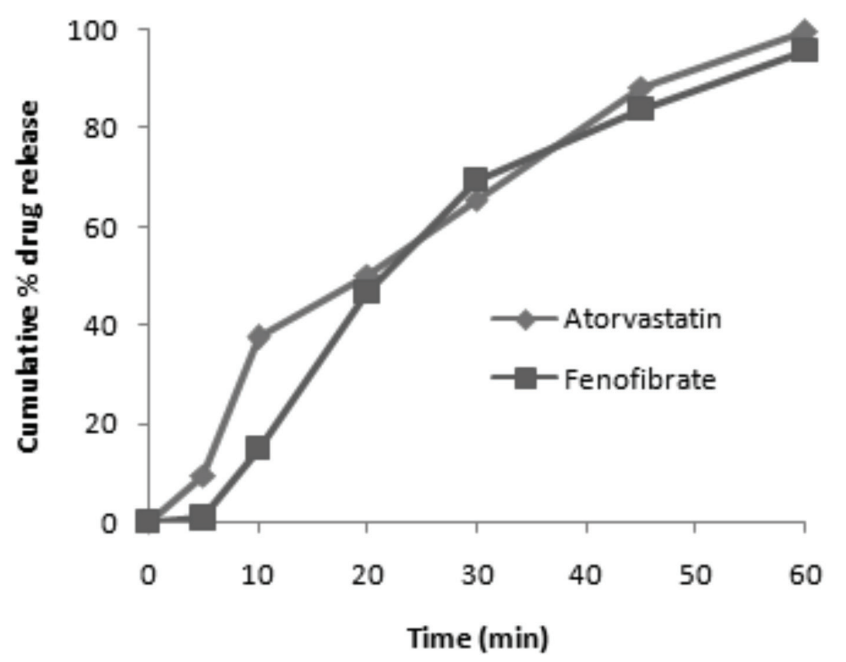

Figure 4. In vitro dissolution profiles of Fibator tablets in 0.5\% W/V SLS medium

SLS: Sodium lauryl sulfate 


\section{Discriminatory power of the dissolution method}

The discriminatory power of the dissolution method was determined by manufacturing tablets under different conditions and studying the behavior of those products in the proposed dissolution method. The effects of tablet hardness $\left(5 \mathrm{~kg} / \mathrm{cm}^{2}\right.$ vs. $8 \mathrm{~kg} / \mathrm{cm}^{2}$ ) and disintegrant (with vs. without) are shown in Figure 5. The dissolution data were calculated with the help of factors of comparison using 6 points; among these, one point was found to specify the drug release more than $85 \%$ (Table 2). These results confirmed that the dissolution test procedure has the ability to discriminate for distinct composition and process, and, based on these results, $0.5 \% \mathrm{w} / \mathrm{v}$ SLS medium has discriminating power.

Stability determination of atorvastatin and fenofibrate in dissolution medium

The stability of drugs in dissolution medium at different time periods was calculated in order to demonstrate the integrity

\section{Table 2. Dissimilarity factor $\left(f_{1}\right)$ and similarity factor $\left(f_{2}\right)$ for} dissolution profiles of tablets

\begin{tabular}{lllll} 
& \multicolumn{2}{l}{$\begin{array}{l}\text { Tablets with hardness of } \\
\text { Name of the drug }\end{array}$} & \multicolumn{2}{l}{$\begin{array}{l}\text { Tablets with disintegrant } \\
\text { vs. no disintegrant }\end{array}$} \\
\cline { 2 - 5 } f $f_{1}$ value & $f_{2}$ value & $f_{1}$ value & $f_{2}$ value \\
\hline Atorvastatin & 16 & 45.44 & 12 & 46.70 \\
\hline Fenofibrate & 17 & 48.30 & 16 & 47.81 \\
\hline
\end{tabular}
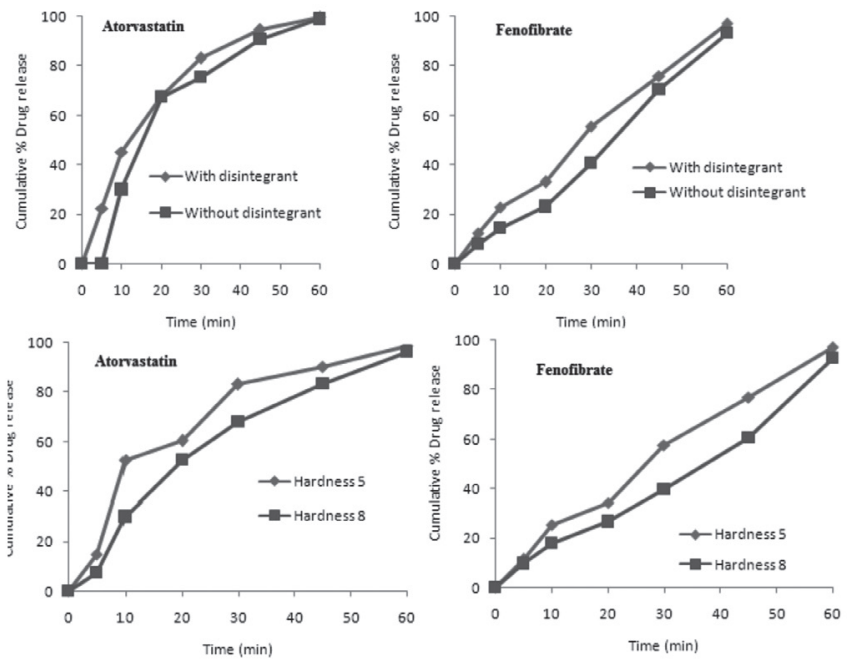

Figure 5. Dissolution profiles of atorvastatin/fenofibrate self-punched tablets in $0.5 \% \mathrm{w} / \mathrm{v}$ SLS medium

SLS: Sodium lauryl sulfate of the drugs and is given in Table 3, showing that both drugs were stable under dissolution test conditions. The change in drug content was not assessed and likewise no evidence of degradation denotes that the solutions were stable for more than $48 \mathrm{~h}$.

Table 3. Data for stability of atorvastatin and fenofibrate dissolution samples

\begin{tabular}{llll}
\multirow{2}{*}{ Analyte } & \multicolumn{3}{l}{$\%$ Amount of drug found $(\mathrm{AM} \pm \mathrm{SD})(\mathrm{n}=3)$} \\
\cline { 2 - 4 } & Initial time & After $24 \mathrm{~h}$ & After $48 \mathrm{~h}$ \\
\hline Atorvastatin & $98.24 \pm 0.45$ & $99.47 \pm 1.24$ & $99.05 \pm 0.58$ \\
\hline Fenofibrate & $99.54 \pm 0.34$ & $100 \pm 0.32$ & $98.54 \pm 0.98$ \\
\hline
\end{tabular}

SD: Standard deviation

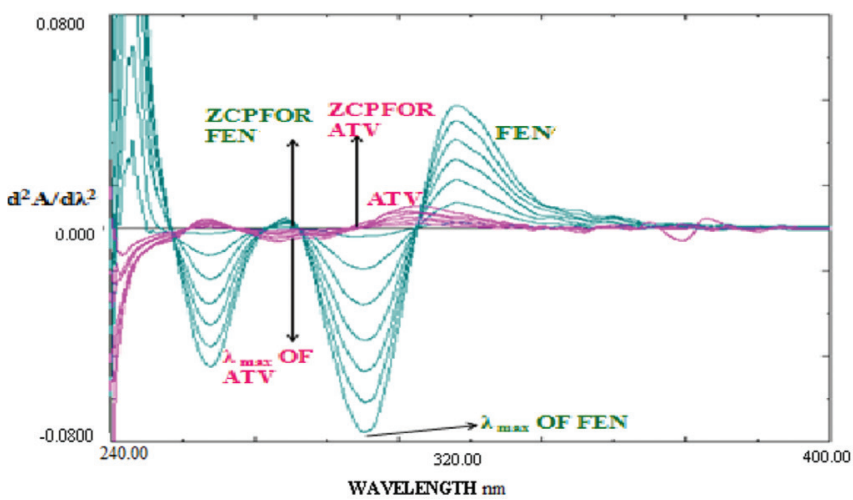

Figure 6. Second-order derivative linearity spectra of ATV and FEN ATV: Atorvastatin, FEN: Fenofibrate

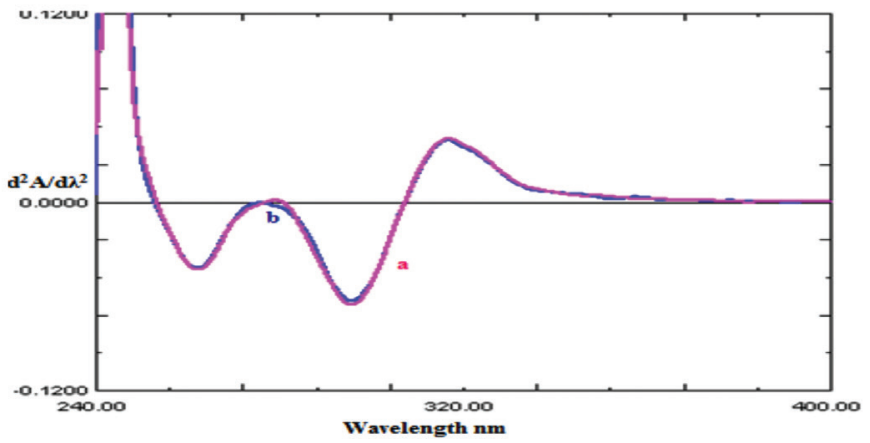

Figure 7. Second-order derivative overlay spectra of commercial formulation (a), standard mixture (b)

Table 4. Precision data of atorvastatin and fenofibrate for the proposed dissolution method

\begin{tabular}{lllllllll} 
& \multicolumn{1}{l}{ Percent amount of atorvastatin } \\
\cline { 2 - 9 } Product & Intra-day & \multicolumn{5}{c}{ Percent amount of fenofibrate } \\
& Mean \pm SD & $\%$ RSD & Mean \pm SD & $\%$ RSD & Mean \pm SD & $\%$ RSD & Mean \pm SD & $\%$ RSD \\
\hline Atocor & $98.86 \pm 1.751$ & 1.77 & $99.45 \pm 1.82$ & 1.83 & $99.17 \pm 2.203$ & 0.22 & $98.24 \pm 2.02$ & 1.05 \\
\hline Fibator & $98.49 \pm 1.604$ & 1.62 & $98.49 \pm 1.54$ & 1.56 & $95.89 \pm 0.479$ & 0.49 & $96.84 \pm 0.54$ & 0.55 \\
\hline
\end{tabular}

SD: Standard deviation, RSD: Relative standard deviation 


\section{Dissolution method validation}

\section{Linearity}

Linearity was assessed by the regression equation of calibration curve method. The responses for atorvastatin at 281 $\mathrm{nm}$ were linear in the concentration range of $2-12 \mu \mathrm{g} / \mathrm{mL}$, with a correlation coefficient $\left(R^{2}\right)$ of 0.9971 ; likewise the responses for fenofibrate at $296 \mathrm{~nm}$ were linear in the concentration range of 1-35 $\mu \mathrm{g} / \mathrm{mL}$, with a $\mathrm{R}^{2}$ of 0.998 . The results indicate a good linear relationship between derivative response and concentrations at $281 \mathrm{~nm}$ and $296 \mathrm{~nm}$ (Figure 6).

\section{Specificity}

The derivative spectrum attained from the commercial formulation solution was correlated with the spectrum of the synthetic mixture of standard solutions (atorvastatin and fenofibrate). The spectra of the commercial formulation and synthetic mixture were superimposed. No interference was seen from excipients with derivative response of either of the drugs (atorvastatin and fenofibrate) at their respective analytical wavelengths of $281 \mathrm{~nm}$ and $296 \mathrm{~nm}$ (Figure 7); hence the method was found to be specific.

\section{Precision}

The precision evaluation data for the dissolution studies are given in Table 4, and they show that percent relative standard deviation values for intra-day and inter-day precision studies were less than 2 and there were no significant differences, indicating that the proposed method was reproducible and precise.

\section{Accuracy}

The accuracy assessment data for the dissolution studies are given in Table 5. They show that percent recovery was from $96 \%$ to $106 \%$ and percent relative standard values were less than 2, indicating that an agreement between the standard values and ascertained values signifies that the dissolution method was accurate.

\section{CONCLUSIONS}

The present investigation was undertaken with the objective to develop and validate a single test method for the dissolution evaluation of atorvastatin calcium and fenofibrate simultaneously. The optimal conditions for dissolution testing of atorvastatin and fenofibrate are as follows: $900 \mathrm{~mL}$ of $0.5 \% \mathrm{w} / \mathrm{v}$ SLS, using a paddle-type USP dissolution apparatus, stirring speed of $50 \mathrm{rpm}$, a temperature of $37 \pm 0.5^{\circ} \mathrm{C}$, and collection time of $60 \mathrm{~min}$. The proposed dissolution test conditions have discriminative power, substantiated the usefulness of this biorelevant medium for the two drugs, and the dissolution method was validated (\% RSD <2). The developed dissolution method can be fruitfully employed as a quality control tool as well as a research tool.

\section{ACKNOWLEDGEMENTS}

The authors are grateful to the management of Gokaraju Rangaraju College of Pharmacy for providing the necessary facilities and infrastructure to carry out this research work.
Conflict of Interest: No conflict of interest was declared by the authors.

\section{REFERENCES}

1. Dressman J, Kramer J. Pharmaceutical dissolution testing (1st ed). London; Taylor and Francies; 2007:92-98.

2. Subrahmanyam CVS. Physical pharmaceutics (2nd ed). Delhi, India; Vallabh Prakashan; 2005:85-96. p.

3. Wang J, Flanagan DR. Fundamentals of dissolution (1st ed). New York; Academic Press; 2009:309-318.

4. Anumolu PD, Sunitha G, Bindu SH, Satheshbabu PR, Subrahmanyam CV. Development and validation of discriminating and biorelevant dissolution test for lornoxicam tablets. Indian J Pharm Sci. 2015;77:312-320.

5. Soni T, Nagda E, Tejal G, Chotai N. Development of discriminating method for dissolution of aceclofenac marketed formulations. Dissolution Technologies. 2008;15:31-34.

6. Dressman JB, Amidon GL, Reppas C, Shah VP. Dissolution testing as prognostic tool for oral drug absorption: immediate release dosage forms. Pharm Res. 1998;15:11-22.

7. Oliveira EFS, Aievedo RCP, Bonfilio R, Oliveira DB, Rebeiro GP, Araujo MB. Dissolution test optimization for meloxicam in the tablet pharmaceutical form. Braz J Pharm Sci. 2009;45:67-73.

8. He Z, Zhong D, Chen X, Liu X, Tang X, Zhao L. Development of a dissolution medium for nimodipine tablets based on bioavailabity evaluation. Eur $J$ Pharm Sci. 2004;21:487-491.

9. Anumolu PD, Venkataraju Y, Gurrala S, Puvvadi S, Subrahmanyam CVS Development of biorelevant and discriminating method for dissolution of efavirenz and its formulations. Asian J Pharm Clin Res. 2012;5:220-223.

10. Menegola J, Steppe M, Schapoval EE. Dissolution test for citalopram in tablets and comparison of in vitro dissolution profiles. Eur J Pharm Biopharm. 2007;67:524-530.

11. Anthony CM, David MO, Brian W. Clarke's analysis of drugs and poisons (3rd ed). London; Pharmaceutical Press, 2004.654.

12. Indian pharmacopoeia (7th ed). Ghaziabad; The Indian Pharmacopoeia Commission; 2014:1099-1744.

13. Vignaduzzo SE, Castellano PM, Kaufman TS. Development and validation of a dissolution test for meloxicam and pridinol mesylate from combined tablet formulation. India J Pharm Sci. 2010;72:197-203.

14. Anumolu PD, Neeli S, Anuganti H, Ranganatham SBP, Satya SCV. Development of dissolution test method for a telmisartan/amlodipine besylate combination using synchronous derivative spectrofluorimetry. Braz J Pharm Sci. 2014;50:330-336.

15. Huang Z, Lozano R, Francis R, Aubry AF, Stecbeck A, Sociascia DO. Development of a single in vitro dissolution method for a combination trilayer tablet formulation of clopidogrel and pravastatin. Dissolution Technologies. 2011;18:12-19.

16. Bhokare PS, Kane RN, Desai DS. Simultaneous spectrophotometric estimation of atorvastatin and fenofibrate in bulk drug and dosage form by using dual wavelength method. IJRPBS. 2012;3:1448-1453.

17. Deepan T, Paul Ambethkar K, Vijaya Laksjmi G, Dhanaraaju MD. Analytical method development and validation of RP-HPLC for estimation of atorvastatin calcium and fenofibrate in bulk drug and tablet dosage forms. Eur J App Sci. 2011;3:35-39. 
18. Dhabale PN, Gharge DS. Simultaneous spectrophotometric estimation of atorvastatin and fenofibrate in bulk drug and dosage form by using simultaneous equation method. International Journal of Chem Tech Research. 2010;2:325-328.

19. Hirave R, Bendagude R, Kondawar M. RP-HPLC method for simultaneous estimation of atorvastatin calcium and fenofibrate in tablet dosage forms. J Pharm Res. 2010;3:2400-2402.

20. Anumolu PD, Gurrala S, Yeradesi VR, Puvvadi SBR, Chavall SVS. Development of dissolution test method for drotaverine hydrochloride/ mefenamic acid combination using derivative spectrophotometry. Trop J Pharm Res. 2013;12:227-232.

21. Mark H, Workman J. Derivatives in spectroscopy Part II- The true derivative. Spectroscopy 2003;18:32-33.

22. Raymond CR, Paul JS, Sian CO. Hand book of pharmaceutical excipients (2nd ed). Chicago; London; Pharmaceutical Press: American Pharmacists Association; 2007;132:385-725. 